\title{
Performance of a successive hydrolysis, denitrification and nitrification system for simultaneous removal of COD and nitrogen from terramycin production wastewater
}

\author{
W.L. Ma ${ }^{\mathrm{a}, \mathrm{b}}$, R. Qi ${ }^{\mathrm{a}}$, Y. Zhang ${ }^{\mathrm{a}}$, J. Wang ${ }^{\mathrm{a}, \mathrm{c}}$, C.Z. Liang ${ }^{\mathrm{a}, \mathrm{d}}$, M. Yang $^{\mathrm{a}, *}$ \\ a State Key Laboratory of Environmental Aquatic Chemistry, Research Center for Eco-Environmental Sciences, \\ Chinese Academy of Sciences, 18 Shuangqing Road, Haidian District, Beijing, 100085, China \\ ${ }^{\mathrm{b}}$ Environmental Engineering Dept., the Inst. of Environment and Energy Engineering, Beijing University of \\ Civil Engineering \& Architecture, Beijing, 100044, China \\ c School of Environmental and Safety Engineering, Jiangsu Polytechnic University, Changzhou, 213164, China \\ d Department of Environmental Engineering, Beijing Institute of Petrochemical Technology, Beijing, 102617, China
}

\section{A R T I C L E I N F O}

\section{Article history:}

Received 12 August 2008

Received in revised form 17 December 2008

Accepted 5 February 2009

\section{Keywords:}

Antibiotics wastewater

Simultaneous removal of COD and nitrogen

Nitrification

Denitrification

\begin{abstract}
A B S T R A C T
A bench-scale continuous flow system, consisting successively of an anaerobic hydrolysis column (column A), an anoxic column (column D) and two aerobic columns (columns B and F), was constructed to remove nitrogen and carbon simultaneously from terramycin crystallization mother solution (TCMS). Columns A and D were sludge-bed reactors, and columns B and F were biofilm reactors packed with polyethylene balls and soft fibers hung on plastic rings, respectively. Approximately $82 \%$ of the chemical oxygen demand (COD) and $81 \%$ total nitrogen were removed by the system when tap water diluted TCMS was continuously fed (dilution ratio, 1:4). Sulfide which was produced during anaerobic hydrolysis was used as part of electron donors for denitrification in column D. Comparison results show that porous polyethylene balls had a better $\mathrm{COD}$ and $\mathrm{NH}_{4}{ }^{+}-\mathrm{N}$ removal performance than the fiber type biocarrier.
\end{abstract}

(c) 2009 Elsevier B.V. All rights reserved.

\section{Introduction}

With the increasing concerns on eutrophication of the enclosed water bodies, control of nutrient discharge is becoming an issue of worldwide concern. One of the most economical and effective means of nitrogen removal is biological nitrification followed by heterotrophic denitrification [1], which has long been applied in municipal wastewater treatment. For industrial wastewater treatment, however, things become complicated because the characteristics of wastewater vary case by case. Wastewater from antibiotics production, for example, usually contains large amounts of fermentation products, some residual antibiotics, and a high concentration of ammonia [2-5]. Some fermentation byproducts may not be easily utilized by denitrifiers as electron donors, and the residual antibiotics have a toxic effect on microorganisms [6].

Most of the recent studies have mainly focused on the behaviors of residual antibiotics during wastewater treatment. Although there have been some studies regarding chemical oxygen demand

\footnotetext{
* Corresponding author. Tel.: +86 10 62923475; fax: +861062923541.

E-mail address: yangmin@rcees.ac.cn (M. Yang).
}

(COD) removal from tetracycline antibiotics production wastewater, researches on the simultaneous removal of COD and nitrogen have been very limited [6-9]. Anaerobic hydrolysis has been considered to be an effective method in improving denitrification efficiency by providing favorable electron donors such as acetate and sulfide when the original organics in wastewater are not easy to be utilized by nitrifiers $[10,11]$. In our previous study, we also found that anaerobic hydrolysis was also very useful in increasing denitrification reaction rates by decomposing complicated molecules to smaller ones, and a successive process of hydrolysis, denitrification, and nitrification was effective for simultaneous removal of COD and nitrogen under a terramycin crystallization mother solution (TCMS) dilution ratio of $1: 9[6]$.

In this paper, a pilot plant system, which included a sludgebed hydrolysis column, a sludge-bed denitrification column, and two biofilm nitrification columns, each using different biocarriers, were further constructed to demonstrate the effectiveness of such a system for treating TCMS under a dilution ratio of $1: 4$. The performance of the system was evaluated over a period of 175 days, and the contribution of each reactor to COD and nitrogen removal was examined in detail. The positions of the two-biofilm nitrification reactors were exchanged on day 85 to compare their nitrification efficiency. 
Table 1

Composition of terramycin crystalization mother solution. Unit: $\mathrm{mg} \mathrm{L}^{-1}$.

\begin{tabular}{lc}
\hline Index & Concentration \\
\hline $\mathrm{COD}$ & 10,783 \\
$\mathrm{BOD}$ & 1,824 \\
$\mathrm{SS}$ & 2,180 \\
$\mathrm{TN}$ & 2,097 \\
$\mathrm{NH}_{4}{ }^{+}-\mathrm{N}$ & 1,639 \\
$\mathrm{NO}_{3}{ }^{-}-\mathrm{N}$ & 100 \\
$\mathrm{TP}^{2-}$ & 122 \\
$\mathrm{SO}_{4}{ }^{2-}$ & 5,850 \\
\hline
\end{tabular}

\section{Methods and materials}

\subsection{Wastewater and sludge sources}

TCMS was taken from a pharmaceutical factory once a month, and stored in $4 \pm 2{ }^{\circ} \mathrm{C}$ refrigerator before use. Its pH was about 4.0, and its main composition is shown in Table 1.

When our previous study [6] ended, sludge in the hydrolysis and denitrification reactors was separately stored at $4 \pm 2{ }^{\circ} \mathrm{C}$ for 3 months, and polyethylene balls covered with biofilm were kept at room temperature for 3 months following drainage of water. Before the starting of this experiment, the polyethylene balls were packed into column $\mathrm{B}$ along with $8.8 \mathrm{~L}$ fresh balls.

Another nitrification column (column F) packed with polyethylene fibers, which were hung on plastic rings, were inoculated with the effluent from column B.

\subsection{Experimental designs}

As shown in Fig. 1, an anaerobic column (column A, $\Phi 80 \mathrm{~mm}$, $\mathrm{H} 1250 \mathrm{~mm}$ ), a denitrification column (column D, $\Phi 80 \mathrm{~mm}$, $\mathrm{H} 1000 \mathrm{~mm}$ ), and two aerobic nitrification columns (column B, $\Phi 120$ mm, H1400 mm; column F, $\Phi 120$ mm, H1900 mm) were used to construct the TCMS treatment system. Both columns A and D were upflow sludge blanket (USB) type reactors equipped with a 2 rpm stirrer.

Firstly, columns A, D and B were started up by inoculating them with sludge used in the previous study [6] at hydraulic retention times (HRTs) of $8.6 \mathrm{~h}, 6.7 \mathrm{~h}$ and $34 \mathrm{~h}$, respectively. The recycling ratio from column B to column D was 1:3 in the beginning. On day 42 , column F was separately started with the effluent from column B as its influent at an HRT of $55 \mathrm{~h}$. One week later, column F was connected into the system to receive the effluent from column $\mathrm{B}$, and the effluent of column $\mathrm{F}$ was returned to column $\mathrm{D}$.

From days 49 to 65 , the effect of recycling flow ratio $(1: 3,1: 4$ and $1: 5)$ on denitrification was determined. Then, the system was operated at a recycling ratio of 3.5:1 until the end of the experiment.

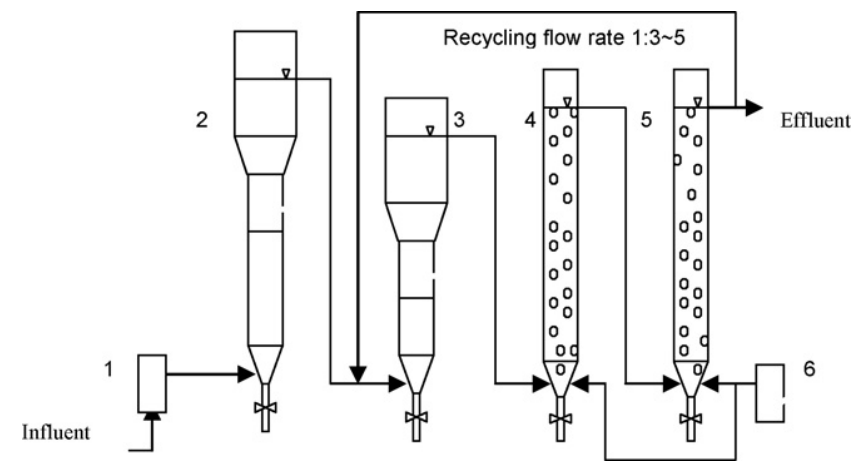

Fig. 1. Diagram of continuous flow treatment system: (1) water pump; (2) anaerobic hydrolysis column; (3) denitrification column; (4) aerobic column; (5) aerobic column; (6) air pump.
On day 85, the positions of columns $\mathrm{B}$ and $\mathrm{F}$ were exchanged in order to compare the performance of the two reactors. The other conditions were not changed further.

All of the columns were kept in a room with a constant temperature of $20 \pm 1{ }^{\circ} \mathrm{C}$ throughout the whole experimental period. TCMS was diluted with tap water at a ratio of $1: 4$. The effluent $\mathrm{pH}$ was kept in a range of $7.8-8.4$ by adding $\mathrm{Na}_{2} \mathrm{CO}_{3}$ or $\mathrm{NaHCO}_{3}$ to the influent. The dissolved oxygen (DO) in aerobic columns was kept in a range from 5 to $8 \mathrm{mg} \mathrm{L}^{-1}$ all the time.

When the continuous experiment ended, some of the sludge from column $\mathrm{D}$ was used to determine the denitrification rate on two electron donors: acetate and sulfide. The test was conducted in $500 \mathrm{~mL}$ beakers with $300 \mathrm{~mL}$ synthetic wastewater containing $100 \mathrm{mg} \mathrm{L}^{-1}$ nitrate nitrogen and one of the electron donors ( $1000 \mathrm{mg} \mathrm{L}^{-1}$ acetate or $300 \mathrm{mg} \mathrm{L}^{-1}$ sulfide). The mixed liquid suspended solids (MLSSs) for tests on acetate and sulfide were $9500 \mathrm{mg} \mathrm{L}^{-1}$ and $6300 \mathrm{mg} \mathrm{L}^{-1}$, respectively. The mixed liquid was mixed in a jar tester at a rotation rate of $18 \mathrm{rpm}$.

\subsection{Analytical methods}

The $\mathrm{pH}$ and $\mathrm{DO}$ were measured on a daily basis with handy meters (pH, HM-14P; DO, DO-11P; TOA Electronics Ltd., Japan) immediately after sampling. For chemical analysis, all samples were filtered with a $0.45-\mu \mathrm{m}$ filter before determination. Ammonia nitrogen $\left(\mathrm{NH}_{4}{ }^{+}-\mathrm{N}\right)$ and total nitrogen (TN) were determined according to [12]. Nitrate nitrogen $\left(\mathrm{NO}_{3}{ }^{-}-\mathrm{N}\right)$, nitrite nitrogen $\left(\mathrm{NO}_{2}{ }^{-} \mathrm{N}\right)$ and sulfate $\left(\mathrm{SO}_{4}{ }^{2-}\right)$ were determined using ion chromatography (IC100, YEW, Japan), and COD was measured with a rapid COD analyzing meter (CTL-12, Huatong, Chengde, Hebei).

\section{Results and discussion}

The continuous experiment lasted for 175 days. Performance of the system in nitrogen and COD removals was studied.

\subsection{Nitrogen removal}

\subsubsection{Ammonia removal}

Fig. 2 shows the ammonia removal performance of the system during the whole experimental period. The average $\mathrm{NH}_{4}{ }^{+}-\mathrm{N}$ removal was calculated to be only $32 \%$ before day 48 , indicating that the nitrification capacity of the three-column system was not sufficient. In order to strengthen the system's nitrification capacity, column $\mathrm{F}$, which was inoculated with the effluent from column B on day 42 , was combined into the system on day 49 . As soon as column $\mathrm{F}$ was introduced, the $\mathrm{NH}_{4}{ }^{+}-\mathrm{N}$ removal of the system increased to $89 \%$. From then on, the $\mathrm{NH}_{4}{ }^{+}-\mathrm{N}$ removal continued to increase, reaching more than $97 \%$ on day 77 , and the effluent $\mathrm{NH}_{4}{ }^{+}-\mathrm{N}$ was below $10 \mathrm{mg} \mathrm{L}^{-1}$ in most cases, even when the influent $\mathrm{NH}_{4}{ }^{+}-$ $\mathrm{N}$ was increased from $320 \mathrm{mg} \mathrm{L}^{-1}$ to $560 \mathrm{mg} \mathrm{L}^{-1}$. The positions

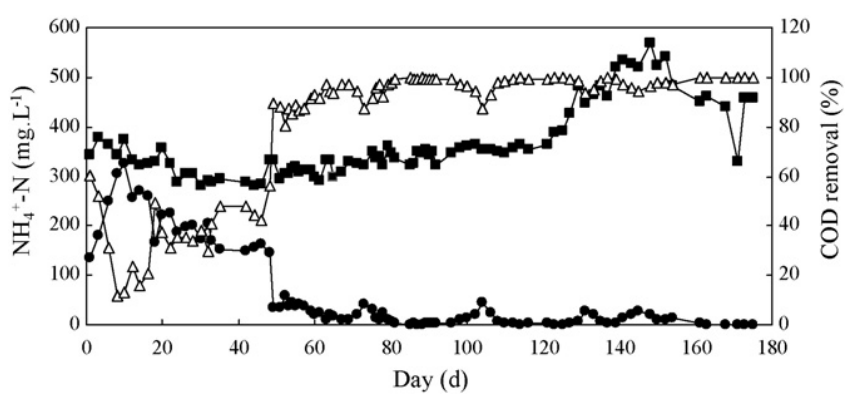

Fig. 2. Ammonia removal performance of the system: $(\boldsymbol{\square})$ influent; $(\bullet)$ effluent; $(\triangle)$ removal. 


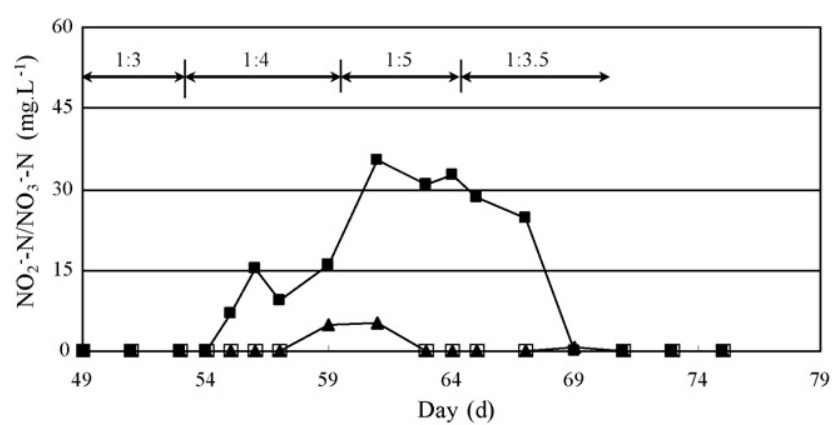

Fig. 3. Effect of recycling flow ratio on denitrification: ( $\boldsymbol{\Lambda}) \mathrm{NO}_{3}{ }^{-}-\mathrm{N}$ and ( $\left.\boldsymbol{\square}\right) \mathrm{NO}_{2}{ }^{-}-\mathrm{N}$.

of columns B and $\mathrm{F}$ were exchanged on day 85 , which led to a slight improvement of nitrification performance of the system.

Periodically the effluent $\mathrm{NH}_{4}^{+}-\mathrm{N}$ rose to as high as over $25 \mathrm{mg} \mathrm{L}^{-1}$, which was attributed to the excessive growth of biofilm on the surfaces of biocarriers. The effluent $\mathrm{NH}_{4}{ }^{+}-\mathrm{N}$ decreased to no more than $10 \mathrm{mg} \mathrm{L}^{-1}$ soon after the two aerobic columns were washed with air.

\subsubsection{The effect of the recycling flow ratio on denitrification}

The data recorded for days 49-75 explain the effect of recycling flow ratio on denitrification (Fig. 3). The reactors were operated under the recycling flow ratio of 1:3, 1:4, 1:5 in turn from days 49 to 67 . The nitrate and nitrite from the recycling flow were reduced completely in D-column at a recycling ratio of $1: 3$. With the increase of the recycling ratio from $1: 3$ to $1: 4$, residual nitrate and nitrite began to appear in column D's effluent because of a lack of sufficient electron donors in wastewater for denitrification. At a recycling flow ratio of 1:3.5, no accumulation of nitrite or nitrate occurred in the effluent from column $D$. This ratio was then maintained to the end of the experiment. The average total nitrogen removal for the whole system was $81.2 \%$.

\subsubsection{Denitrification electron donors}

Our previous study [6] reported that sulfate in influent was reduced to sulfide during anaerobic hydrolysis. But an increase of sulfate was found during denitrification. The same results were obtained in this experiment. When the experiment ended, denitrification on sulfide and acetate with sludge from column D was tested to determine whether denitrification on sulfide actually had occurred in column D (Fig. 4). It was found that both sulfide and acetate were utilized as denitrification electron donors, indicating the co-existence of autotrophic and heterotrophic denitrification bacteria in column $\mathrm{D}$. The specific denitrification rates using acetate and sulfide were $0.085 \mathrm{~d}^{-1}$ and $0.043 \mathrm{~d}^{-1}$, respectively.

Fig. 5 shows changes of sulfate in column D's influent and effluent. The sulfate averagely increased for $29 \mathrm{mg} \mathrm{L}^{-1}$ after denitrification. It is possible that DO in the returning effluent also

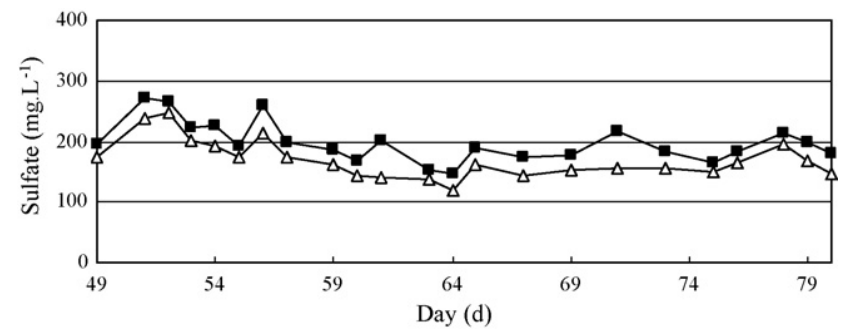

Fig. 5. Changes of sulfate concentrations in D-column: $(\Delta)$ influent and $(\mathbf{\square})$ effluent

contributed to the increase of sulfate. Assuming that the DO in the returning effluent was $6 \mathrm{mg} \mathrm{L}^{-1}$ and that all of the DO was consumed by sulfate production, it is calculated that no more than $9 \mathrm{mg} \mathrm{L}^{-1}$ of sulfate was contributed by DO. It is clear that the increased sulfate was mainly produced through denitrification.

\subsubsection{Comparison of nitrification performance of the two biofilm reactors}

Two types of biocarriers were used in this experiment. One was porous polyethylene balls, and the other was polyethylene fibers hung on plastic rings. The nitrification capacities of the two columns were compared by exchanging the positions of column $\mathrm{F}$ and column B on day 85.

From days 66 to 102, ammonia in the influent was within a range of $300-360 \mathrm{mg} \mathrm{L}^{-1}$. Daily influent and effluent concentrations of ammonia, nitrate and nitrite in two aerobic columns were averaged before and after day 85, respectively (as shown in Tables 2 and 3). It is clear that, no matter which column was used as the first step of aerobic reactor, the $\mathrm{NH}_{4}{ }^{+}-\mathrm{N}$ removal load in the first reactor was higher than that in the second one, which was due to the higher influent ammonia nitrogen concentration in the first aerobic reactor. At the same time, it is clear that as the first stage of aerobic reactor, the $\mathrm{NH}_{4}{ }^{+}-\mathrm{N}$ removal load of column $\mathrm{B}$ was approximately 2 times that of column $\mathrm{F}$, and that as the second reactor, the $\mathrm{NH}_{4}{ }^{+}-\mathrm{N}$ removal load of column $\mathrm{B}$ was 1.4 times that of column F. This result indicates that column B was superior to column $F$ in the aspect of nitrification. The fiber type biocarrier has a very large specific surface area. The lower nitrification load of column $F$ might be attributed to the fact that fibers tend to became agglomerated, resulting in lower contact efficiency between wastewater and microbes in the biofilm.

\section{2. $C O D$ removal}

\subsubsection{COD removal performance of the system}

Fig. 6 shows the COD removal performance of the system. During the whole experimental period, the COD removal varied around $82 \%$. The introduction of column F into the system on day 49 only
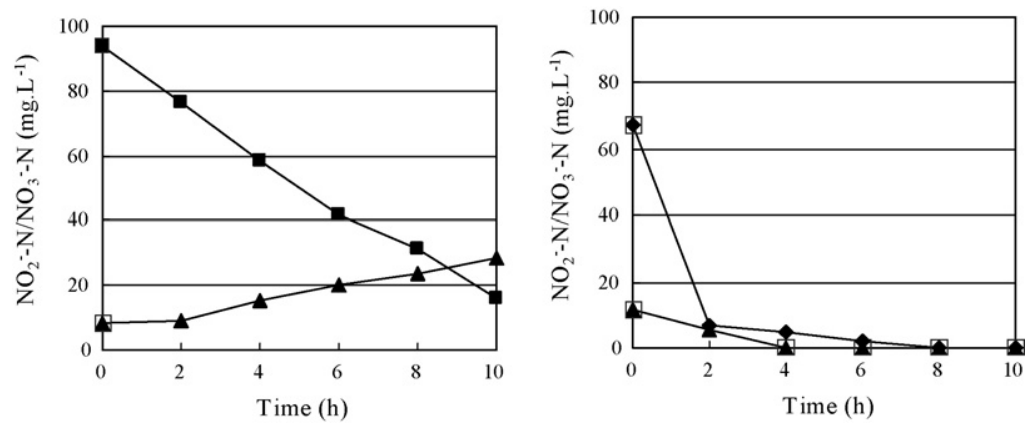

Fig. 4. Denitrification tests using sulfide and acetate as electron donors: ( $\mathbf{\square}) \mathrm{NO}_{3}^{-}-\mathrm{N}$ and $(\boldsymbol{\Delta}) \mathrm{NO}_{2}{ }^{-}-\mathrm{N}$. 
Table 2

The performance of B-column.

\begin{tabular}{|c|c|c|c|c|c|}
\hline Index & Stage & Influent ( $\left.\mathrm{mg} \mathrm{L}^{-1}\right)$ & Effluent (mg L $\left.{ }^{-1}\right)$ & Concentration change $\left(\mathrm{mg} \mathrm{L}^{-1}\right)$ & Ammonia removal load, $\mathrm{kg} \mathrm{m}^{-3} \mathrm{~d}^{-1}$ \\
\hline \multirow[t]{2}{*}{$\mathrm{NH}_{4}{ }^{+}-\mathrm{N}$} & I & 90.43 & 28.89 & -61.54 & 0.195 \\
\hline & II & 33.66 & 5.32 & -28.34 & 0.056 \\
\hline \multirow[t]{2}{*}{$\mathrm{NO}_{3}{ }^{-}-\mathrm{N}$} & I & 0.24 & 43.39 & 43.15 & - \\
\hline & II & 41.56 & 75.52 & 33.96 & - \\
\hline \multirow[t]{2}{*}{$\mathrm{NO}_{2}{ }^{-}-\mathrm{N}$} & I & 5.13 & 17.82 & 12.69 & - \\
\hline & II & 9.47 & 0 & -9.47 & - \\
\hline
\end{tabular}

Days 66-84: as the first step of aerobic column. Days 85-102: as the second step of aerobic column.

Table 3

The performance of F-column.

\begin{tabular}{|c|c|c|c|c|c|}
\hline Index & Stage & Influent ( $\left.\mathrm{mg} \mathrm{L}^{-1}\right)$ & Effluent $\left(\mathrm{mg} \mathrm{L}^{-1}\right)$ & Concentration change $\left(\mathrm{mg} \mathrm{L}^{-1}\right)$ & Ammonia removal load, $\mathrm{kg} \mathrm{m}^{-3} \mathrm{~d}^{-1}$ \\
\hline $\mathrm{NH}_{4}{ }^{+}-\mathrm{N}$ & $\begin{array}{l}\text { I } \\
\text { II }\end{array}$ & $\begin{array}{l}85.79 \\
28.89\end{array}$ & $\begin{array}{l}33.66 \\
16.47\end{array}$ & $\begin{array}{l}-52.13 \\
-12.42\end{array}$ & $\begin{array}{l}0.102 \\
0.039\end{array}$ \\
\hline $\mathrm{NO}_{3}{ }^{-}-\mathrm{N}$ & $\begin{array}{l}\text { I } \\
\text { II }\end{array}$ & $\begin{array}{c}0 \\
43.39\end{array}$ & $\begin{array}{l}41.56 \\
61.5\end{array}$ & $\begin{array}{l}41.56 \\
18.11\end{array}$ & $\begin{array}{l}- \\
-\end{array}$ \\
\hline $\mathrm{NO}_{2}{ }^{-}-\mathrm{N}$ & $\begin{array}{l}\text { I } \\
\text { II }\end{array}$ & $\begin{array}{c}0 \\
17.82\end{array}$ & $\begin{array}{r}9.47 \\
10.34\end{array}$ & $\begin{array}{r}9.47 \\
-7.48\end{array}$ & $\begin{array}{l}- \\
-\end{array}$ \\
\hline
\end{tabular}

Days 85-102: as the first step of aerobic column. Days 66-84: as the second step of aerobic column.

resulted in a slight increase of COD removal, indicating that the remaining COD was resistant to biological degradation, and that further treatment with some physical chemical method is necessary to decrease the COD. The effluent COD varied in a range between 400 and $500 \mathrm{mg} \mathrm{L}^{-1}$ with the increase of influent COD from $2000 \mathrm{mg} \mathrm{L}^{-1}$ to $3300 \mathrm{mg} \mathrm{L}^{-1}$, demonstrating that the system was stable in terms of COD removal.

Of the $82 \%$ average COD removal, nearly half was attributed to denitrification in column D (40\%) (Fig. 7). Hydrolysis, the first aerobic treatment, and the second aerobic treatment removed 10\%, $24 \%$

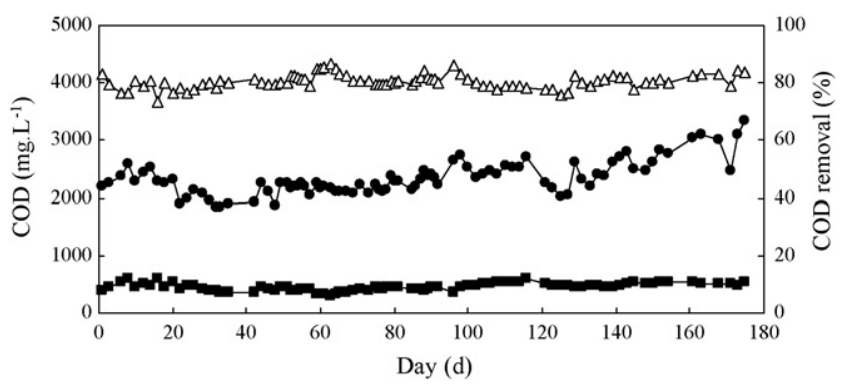

Fig. 6. COD removal of the total system: $(\bullet)$ influent; $(\boldsymbol{\square})$ effluent; $(\Delta)$ removal.

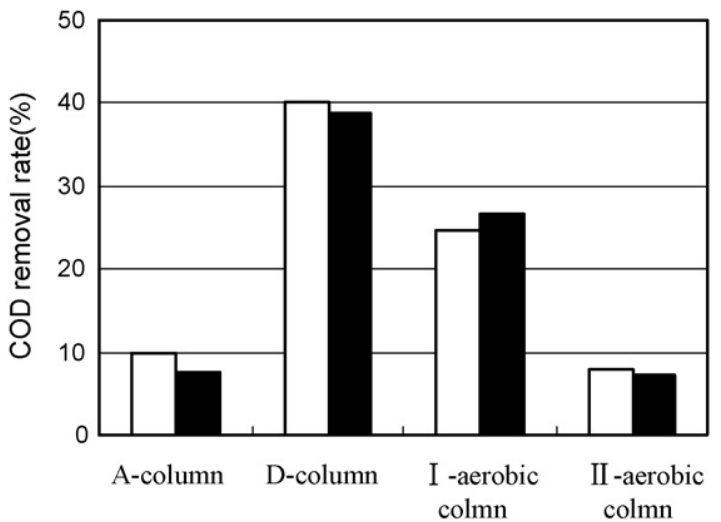

Fig. 7. COD removal in each column before and after position exchange of B- and F-columns $(\square)$ before and $(\boldsymbol{\square})$ after.
Table 4

COD removal load of each column. Unit: $\mathrm{kg} \mathrm{m}^{-3} \mathrm{~d}^{-1}$.

\begin{tabular}{lllll}
\hline Time & A-column & D-column & B-column & F-column \\
\hline Days 51-84 & 0.60 & 3.15 & $0.37^{\mathrm{a}}$ & $0.074^{\mathrm{b}}$ \\
Days 85-175 & 0.52 & 3.34 & $0.12^{\mathrm{b}}$ & $0.28^{\mathrm{a}}$ \\
\hline
\end{tabular}

a To act as the first aerobic column.

b To act as the second aerobic column.

and $8 \%$ of COD, respectively. The exchange of positions of columns $\mathrm{B}$ and $\mathrm{F}$ on day 85 did not affect COD removal markedly.

\subsubsection{COD removal load of each column}

Average volumetric COD removal load for each column from days 51 to 84 and days 85 to 175 was determined, and the results are shown in Table 4 . Following anaerobic hydrolysis in column $\mathrm{A}$, the COD components in wastewater were transformed into small molecular compounds that were easy for denitrifiers to utilize [6]. So the COD removal load of column D was as high as $3.15-3.34 \mathrm{~kg} \mathrm{~m}^{-3} \mathrm{~d}^{-1}$. The COD removal loads in the aerobic columns were not so high because most of organics had been removed in column D. Compared with column F, column B showed a relatively high COD removal rate, too, indicating that the ball type biocarrier was superior to the fiber biocarrier in terms of COD and ammonium removal.

\section{Conclusion}

1. Simultaneous removal of nitrogen and carbon from TCMS diluted at a ratio of 1:4 was achieved with a process of successive anaerobic hydrolysis, denitrification, and nitrification, demonstrating that the system using USB type reactors for hydrolysis and denitrification, and fixed-bed type reactors for nitrification are effective for TCMS treatment.

2. The COD removal was approximately $82 \%$, and the residual COD in the effluent was $400-500 \mathrm{mg} \mathrm{L}^{-1}$. Further removal of COD requires the use of some physical chemical method because of the refractory property of the remaining organic compounds.

3. Autotrophic and heterotrophic denitrification bacteria coexisted in the denitrification column, and both sulfide and organics could be utilized as electron donors for denitrification. The system's TN removal rate was $81 \%$. 
4. Porous polyethylene balls had a higher $\mathrm{COD}$ and $\mathrm{NH}_{4}{ }^{+}-\mathrm{N}$ removal performance than the fiber type biocarrier.

\section{Acknowledgments}

This work was financially supported by the National Natural Science Foundation of China (50525824 and 20877085). The authors thank Mr. L.R. Ren for his assistance in this experimental task.

\section{References}

[1] B.D. Azevedo, D.S. Mavinic, H.D. Robinson, The effect of ammonia loading and operating temperature on nitrification and denitrification of high ammonia landfill leachate, Can. J. Civil. Eng. 22 (3) (1995) 524-534.

[2] C.S. Mcardell, E. Molnar, M.J.F. Suter, G. Walter, Occurrence and fate of macrolide antibiotics in wastewater treatment plants and in the glatt valley watershed, Switzerland, Environ. Sci. Technol. 24 (37) (2003) 5479-5486.

[3] A.J. Watkinson, E.J. Murby, S.D. Costanzo, Removal of antibiotics in conventional and advanced wastewater treatment: implications for environmental discharge and wastewater recycling, Water Res. 41 (18) (2007) 4164-4176.

[4] A. Gulkowska, H.W. Leung, M.K. So, S. Taniyasu, N. Yamashita, Leo.W.Y. Yeung, B.J. Richardson, A.P. Lei, J.P. Giesy, P.K.S. Lam, Removal of antibiotics from wastewater by sewage treatment facilities in Hong Kong and Shenzhen, China, Water Res. 4 (1-2) (2008) 395-403.

[5] J. Benner, E. Salhi, T. Ternes, U. von Gunten, Ozonation of reverse osmosis concentrate: kinetics and efficiency of beta blocker oxidation, Water Res. 42 (12) (2008) 3003-3012.

[6] W.L. Ma, M. Yang, J. Wang, R. Qi, L.R. Ren, Treatment of antibiotics wastewater utilizing successive anaerobic hydrolysis, denitrification and nitrification, Environ. Technol. 23 (2002) 685-694.

[7] Y.Q. Wei, H.J. Wang, Q. Zhang, Research and development of oxytetracycline wastewater treatment, Chongqing Environ. Sci. 25 (6) (2003) 49-51 (in Chinese).

[8] L.Q. Tang, C.D. He, Y.H. Luo, Progresses of treatment technologies for pharmaceutical wastewater containing tetracycline antibiotics, Environ. Sci. Manage. 31 (7) (2006) 99-102.

[9] K. Chen, Q.X. Zhang, Y. Li, Z.J. Zhang, Application on cyclic activated sludge system for oxytetracycline wastewater disposal, J. Henan Agric. Univ. 36 (3)(2002) 276-279 (in Chinese).

[10] E. Rustrian, J.P. Delgenes, N. Bernet, R. Moletta, Nitrate reduction in acidogenic reactor: influence of wastewater $\mathrm{COD} / \mathrm{N}-\mathrm{NO}_{3}$ ratio on denitrification and acidogenic activity, Environ. Technol. 18 (1997) 309-315.

[11] J.M. Garrido, R. Mendez, J.M. Lema, Simultaneous urea hydrolysis, formaldehyde removal and denitrification in a multifed upflow filter under anoxic and anaerobic conditions, Water Res. 35 (3) (2001) 691-696.

[12] Standard Methods of Water and Wastewater Monitoring, 4th ed., State Environmental Protection Administration of China, 2002. 